\title{
A CASE STUDY ON ENERGY SAVINGS IN AIR CONDITIONING SYSTEM BY HEAT RECOVERY USING HEAT PIPE HEAT EXCHANGER
}

\author{
Tushar S. Jadhav' ${ }^{1}$, Mandar M. Lele ${ }^{2}$ \\ ${ }^{1}$ Assistant Professor, Department of Mechanical Engineering, JSPM's JSCOE, Pune, 411028, Maharashtra, India, \\ ${ }^{2}$ Professor, Department of Mechanical Engineering, MAEER's MIT, Pune, 411038, Maharashtra, India,
}

\begin{abstract}
In air conditioning facilities with high outside air requirements such as cleanroom air conditioning systems, considerable energy savings is possible by heat recovery using heat pipe heat exchanger (HPHX).The literature review indicated that the annual energy saving analysis of air conditioning system with HPHX for Indian climatic conditions has not been performed. The paper investigates the possible energy savings using HPHX for heat recovery in air conditioning system for a process air conditioning facility in Pune city, India. The impact of number of rows of HPHX and variations in the operating air conditions on the savings in cooling coil capacity is presented in this paper. The paper also reveals the comparative analysis of annual energy savings with number of rows of HPHX for Pune weather conditions. The application of heat pipe heat exchanger for energy savings in air conditioning system is strongly recommended.
\end{abstract}

Index Terms: Air conditioning, Energy savings, Heat recovery, Heat pipe heat exchanger

\section{INTRODUCTION}

Heat pipe heat exchanger (HPHX) is an excellent device used for heat recovery in air conditioning systems. Among the many outstanding advantages of using the heat pipe as a heat transmission device are constructional simplicity, exceptional flexibility, accessibility to control and ability to transport heat at high rate over considerable distance with extremely small temperature drop [1]. Y.H. Yau and M. Ahmadzadehtalatapeh [2] conducted a literature review on the application of horizontal heat pipe heat exchangers (HPHXs) for air conditioning in tropical climates. The authors investigated the energy saving and dehumidification enhancement aspects of HPHXs and made a summary of experimental and theoretical studies on HPHXs. A literature review on the application of HPHX for heat recovery focused on the energy saving and the enhanced effectiveness of the conventional heat pipe (CHP), two phase closed thermosyphon (TPCT) and oscillating heat pipe (OHP) heat exchanger was conducted by $\mathrm{W}$. Srimuang and $\mathrm{P}$. Amatachaya [3]. G.D. Mathur [4] developed a computer program to calculate the savings in the energy using HPHX on the existing air conditioning systems. The investigation was carried out for 33 United States cities with widely different climatic conditions. J.W. Wan et al. [5] investigated the effect of heat pipe air handling coil on energy consumption in a central air conditioning system with return air. Investigations were made to study the effect of HPHX for energy savings in air conditioning applications $[6-10]$. The literature review indicated that the annual energy saving analysis of air conditioning system with HPHX for Indian climatic conditions has not been performed. This paper focuses on the use of HPHX for energy savings in air conditioning system by considering a case study of process air conditioning facility located in Pune city, India. HPHX can be used for i) exchange of heat between fresh outdoor air and conditioned return air (heat recovery application) and ii) enhancing the dehumidification capability of cooling coil as well as reheat savings (dehumidification enhancement with reheat application) [11]. However, the second application of dehumidification with reheat is beneficial in situation wherein reheating is necessary for maintaining required indoor air conditions. This paper discusses the use of HPHX only for the heat recovery application i.e. exchange of heat between fresh outdoor air and conditioned return air, as it can be used for all the air conditioning applications.

\section{AIR CONDITIONING LOAD ANALYSIS WITH AND WITHOUT HPHX}

A case study on air conditioning load analysis with and without HPHX for process air conditioning facility located in Pune city, India is presented in this paper.

The process air conditioning facility under consideration has an area of $590 \mathrm{~m}^{2}$, height $3.6 \mathrm{~m}$ and occupancy 27 . The Pune outdoor air (OA) conditions used for air conditioning load analysis is $40{ }^{\circ} \mathrm{C}$ DBT and $28 \% \mathrm{RH}$ whereas the return (room) air conditions is $23{ }^{\circ} \mathrm{C}$ DBT and $50 \% \mathrm{RH}$. The 
summary of the air conditioning load analysis without HPHX (considered as Base case condition) is listed in Table 1.

Table - 1: Summary of air conditioning load analysis without HPHX (Base case condition)

\begin{tabular}{|c|c|c|c|c|c|c|c|}
\hline \multirow[t]{2}{*}{ Details } & \multirow{2}{*}{$\begin{array}{c}\text { DBT } \\
{ }^{0} \mathrm{C} \\
\end{array}$} & \multirow{2}{*}{$\begin{array}{c}\text { WBT } \\
{ }^{0} \mathrm{C}\end{array}$} & \multirow{2}{*}{$\begin{array}{c}\text { RH } \\
\% \\
\end{array}$} & \multirow{2}{*}{$\begin{array}{c}\text { W } \\
\mathrm{g} / \mathrm{kg} \\
\end{array}$} & \multirow{2}{*}{$\begin{array}{l}\text { Air } \\
\text { Qty } \\
\mathrm{m}^{3} / \mathrm{s}\end{array}$} & \multicolumn{2}{|c|}{$\begin{array}{c}\text { Maximum } \\
\text { Cooling } \\
\text { Coil } \\
\text { Capacity }\end{array}$} \\
\hline & & & & & & TR & $\mathbf{k W}$ \\
\hline $\mathrm{OA}$ & 40.00 & 24.22 & 28.00 & 13.93 & 0.80 & & \\
\hline RA & 23.00 & 16.07 & 50.00 & 9.39 & 8.03 & & \\
\hline & & & & Total & 8.83 & 51.7 & 182 \\
\hline
\end{tabular}

In conventional air conditioning plant, the return air and outdoor air is mixed before the cooling coil. The cooled supply air leaving the cooling coil is further delivered to the room to pick up the sensible and latent loads in the room. However by using HPHX, the cold exhaust air is used to cool the incoming hot outdoor air. This results in cooling of outdoor air which then gets mixed with return air. The remaining process is similar to conventional air conditioning.

The effect of number of rows of HPHX on the maximum savings in cooling coil capacity for the base case condition with HPHX is shown in Table 2. The values of effectiveness for different number of rows of HPHX are referred using product catalogue of S \& P Coil Products Limited [11].

Table - 2: Effect of number of rows of HPHX on the maximum savings in cooling coil capacity for base case condition with HPHX

\begin{tabular}{|c|c|c|c|c|c|}
\hline \multirow{2}{*}{$\begin{array}{c}\text { ROWS } \\
\text { of } \\
\text { HPHX }\end{array}$} & $\boldsymbol{\varepsilon}$ & $\begin{array}{c}\text { DBT of } \\
\text { Outside Air } \\
\text { leaving } \\
\text { HPHX, }\end{array}$ & $\begin{array}{c}\text { Maximum } \\
\text { Savings in } \\
\text { Cooling } \\
\text { Coil } \\
\text { Capacity }\end{array}$ & $\begin{array}{c}\text { \% } \\
\text { Savings }\end{array}$ \\
\cline { 4 - 6 } & & kW & TR & \\
\hline $\begin{array}{c}\text { Without } \\
\text { HPHX }\end{array}$ & - & 40 & - & - & - \\
\hline 1 & 0.33 & 34.4 & 5.50 & 1.56 & 3.0 \\
\hline 2 & 0.49 & 31.7 & 8.17 & 2.32 & 4.5 \\
\hline 3 & 0.59 & 30.0 & 9.84 & 2.80 & 5.4 \\
\hline 4 & 0.66 & 28.8 & 11.01 & 3.13 & 6.1 \\
\hline 6 & 0.75 & 27.3 & 12.51 & 3.56 & 6.9 \\
\hline 8 & 0.8 & 26.4 & 13.34 & 3.79 & 7.3 \\
\hline 10 & 0.83 & 25.9 & 13.84 & 3.94 & 7.6 \\
\hline 12 & 0.85 & 25.6 & 14.18 & 4.03 & 7.8 \\
\hline 14 & 0.87 & 25.2 & 14.51 & 4.13 & 8.0 \\
\hline 16 & 0.89 & 24.9 & 14.84 & 4.22 & 8.2 \\
\hline
\end{tabular}

The effectiveness of HPHX is ratio of actual heat transfer to the maximum possible heat transfer. Since HPHX involves recovery of only sensible heat, therefore the effectiveness of
HPHX can also be defined as ratio of actual temperature drop to maximum possible temperature drop $[4,10]$.

$$
\begin{aligned}
\varepsilon_{H P H X} & =\frac{T_{O A}-T_{L A}}{T_{O A}-T_{R A}} \\
\therefore T_{L A} & =\left\{T_{O A}-\varepsilon_{H P H X}\left(T_{O A}-T_{R A}\right)\right\}
\end{aligned}
$$

Since the savings in cooling coil capacity due to HPHX is only due to sensible heat, hence the savings in $\mathrm{kW}$ is given by

Savings in Cooling coil capacity, $\mathrm{kW}=0.02044 \times \mathrm{OA} \times 60$ $\mathrm{x}\left(\mathrm{T}_{\mathrm{OA}}-\mathrm{T}_{\mathrm{LA}}\right)$ where $\mathrm{OA}=$ Outside air in $\mathrm{m}^{3} / \mathrm{s}$.

Referring to Table 2, in comparison to the base case condition, we see that there is a saving of more than 3 TR on cooling coil capacity when HPHX with 4 or more rows is installed. This results in significant savings in the initial cost and more important in the operating cost. The variation in maximum savings is between 6.9 to $8.2 \%$ when number of rows of HPHX is more than 6. To study the variations in maximum cooling coil capacity and maximum savings in cooling coil capacity, further investigations are performed by varying the return air conditions whereas the outdoor air conditions are maintained the same $\left(40{ }^{\circ} \mathrm{C}\right.$ DBT, $28 \% \mathrm{RH}$ and $0.8 \mathrm{~m}^{3} / \mathrm{s}$ ).

The following cases are studied.

Case I: Varying the return air DBT between $21-25{ }^{\circ} \mathrm{C}$, keeping RH constant at $50 \%$. The summary of air conditioning load analysis for various conditions of Case $\mathrm{I}$ is shown in Table 3.

Table - 3: Summary of air conditioning load analysis for

\begin{tabular}{|c|c|c|c|c|c|}
\hline \multirow[b]{2}{*}{ Details } & \multicolumn{5}{|c|}{ Return air (RA) conditions } \\
\hline & $\begin{array}{l}23^{0} \mathrm{C} \\
\text { DBT } \\
\text { and } 50 \\
\% \text { RH }\end{array}$ & $\begin{array}{c}24^{0} \mathrm{C} \\
\text { DBT } \\
\text { and 50 } \\
\% \mathrm{RH}\end{array}$ & $\begin{array}{l}25^{\circ} \mathrm{C} \\
\text { DBT } \\
\text { and 50 } \\
\% \mathrm{RH}\end{array}$ & $\begin{array}{l}22^{0} \mathrm{C} \\
\text { DBT } \\
\text { and } 50 \\
\% \text { RH }\end{array}$ & $\begin{array}{c}21^{0} \mathrm{C} \\
\text { DBT } \\
\text { and } 50 \\
\% \mathrm{RH}\end{array}$ \\
\hline $\begin{array}{l}\text { Total air } \\
\text { required, } \\
\mathrm{m}^{3} / \mathrm{s}\end{array}$ & 8.83 & 8.17 & 7.59 & 9.58 & 10.43 \\
\hline $\begin{array}{l}\text { Maximum } \\
\text { Cooling coil } \\
\text { capacity, TR }\end{array}$ & 51.7 & 50.3 & 48.9 & 53 & 54.3 \\
\hline $\begin{array}{l}\text { \% change in } \\
\text { air quantity } \\
\text { with } \\
\text { reference to } \\
\text { base case }\end{array}$ & - & -7.47 & - 14.04 & +8.49 & +18.12 \\
\hline $\begin{array}{l}\text { \% change in } \\
\text { cooling coil } \\
\text { capacity } \\
\text { with } \\
\text { reference to } \\
\text { base case }\end{array}$ & - & -2.70 & -5.41 & +2.51 & +5.02 \\
\hline
\end{tabular}
various conditions of Case I 
Case II: Varying the return air RH between 45 - $55 \%$ keeping DBT constant at $23{ }^{0} \mathrm{C}$. The summary of air conditioning load analysis for various conditions of Case II is shown in Table 4.

Table - 4: Summary of air conditioning load analysis for various conditions of Case II

\begin{tabular}{|c|c|c|c|c|c|}
\hline \multirow[b]{2}{*}{ Details } & \multicolumn{5}{|c|}{ Return air (RA) conditions } \\
\hline & $\begin{array}{l}2{ }^{\circ} \mathrm{C} \\
\text { DBT } \\
\text { and } \\
50 \% \\
\text { RH } \\
\end{array}$ & $\begin{array}{c}23^{\circ} \mathrm{C} \\
\text { DBT } \\
\text { and } \\
52.5 \% \\
\text { RH } \\
\end{array}$ & $\begin{array}{c}23^{\circ} \mathrm{C} \\
\text { DBT } \\
\text { and } \\
55 \% \\
\text { RH } \\
\end{array}$ & $\begin{array}{c}23^{\circ} \mathrm{C} \\
\text { DBT } \\
\text { and } \\
47.5 \% \\
\text { RH } \\
\end{array}$ & $\begin{array}{c}23^{\circ} \mathrm{C} \\
\text { DBT } \\
\text { and } \\
45 \% \\
\text { RH } \\
\end{array}$ \\
\hline $\begin{array}{l}\text { Total air } \\
\text { required, } \\
\mathrm{m}^{3} / \mathrm{s}\end{array}$ & 8.83 & 8.83 & 8.83 & 8.83 & 8.83 \\
\hline $\begin{array}{l}\text { Maximum } \\
\text { Cooling coil } \\
\text { capacity, } \\
\text { TR }\end{array}$ & 51.7 & 51.3 & 51 & 52 & 52.3 \\
\hline $\begin{array}{l}\% \text { change in } \\
\text { air quantity } \\
\text { with } \\
\text { reference to } \\
\text { base case }\end{array}$ & - & - & - & - & - \\
\hline $\begin{array}{l}\% \text { change in } \\
\text { cooling coil } \\
\text { capacity } \\
\text { with } \\
\text { reference to } \\
\text { base case }\end{array}$ & - & -0.77 & -1.35 & +0.58 & +1.16 \\
\hline
\end{tabular}

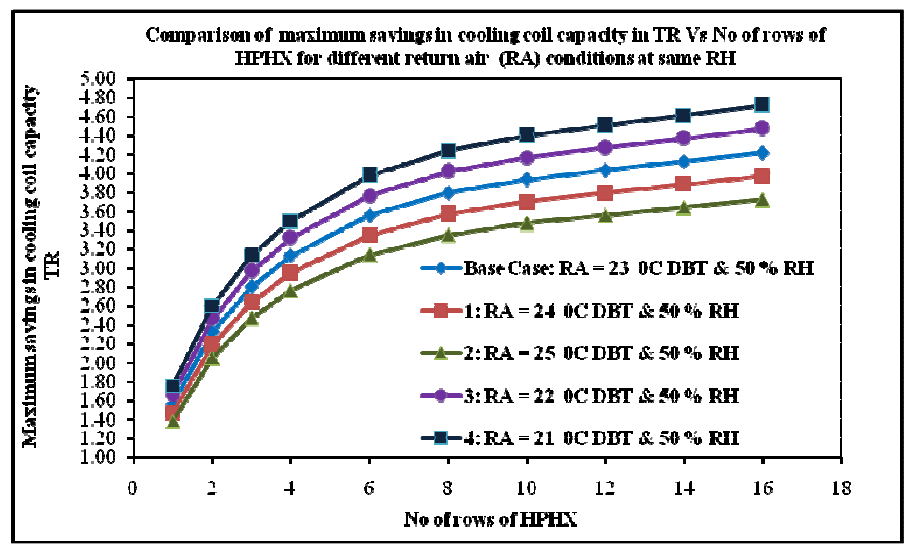

Fig - 1: Comparison of maximum savings in cooling coil capacity in TR Vs No of rows of HPHX for different return air (RA) conditions at same RH.

Figure 1 shows comparative analysis of maximum savings in cooling coil capacity for various combinations of Case I. The values of maximum savings in cooling coil capacity in Fig. 1 are calculated similar to those shown in Table 2.

\section{RESULTS AND DISCUSSIONS}

The lower DBT $\left(21{ }^{0} \mathrm{C}\right)$ proves beneficial in lowering the temperature of air entering the cooling coil via HPHX. This results in more savings in the cooling coil capacity in operating conditions, as seen from Fig. 1. However, from Table 3, the increase in initial cooling coil capacity at RA condition of $21^{\circ} \mathrm{C}$ DBT and $50 \%$ RH compared to the base case condition is $2.6 \mathrm{TR}$ whereas from Fig. 1, the comparative savings in cooling coil capacity using HPHX at $21{ }^{\circ} \mathrm{C}$ DBT and $23{ }^{\circ} \mathrm{C}$ DBT is 0.5 TR when number of rows of HPHX is 16. Thus, considering the overall savings, lower DBT is not beneficial. Referring to Table 4, we see that the variation in maximum cooling coil capacity at $23{ }^{\circ} \mathrm{C}$ DBT and $55 \% \mathrm{RH}$ in comparison to the base case is $0.7 \mathrm{TR}$. This will help in reducing the initial and operating cost of cooling coil. From Table 3 and 4 and Fig. 1, it is observed that out of all the RA conditions studied in this paper, the RA condition of $23{ }^{\circ} \mathrm{C} \mathrm{DBT}$ and $55 \% \mathrm{RH}$ is the best possible condition for getting maximum savings in the initial and operating cost of cooling coil with HPHX.

The HPHX savings for heat recovery between outdoor air and return air are associated with sensible heat. Hence in Case II, the maximum savings in cooling coil capacity using HPHX remains the same in comparison to the base case condition, as the DBT is same.

The savings in cooling coil are significant when the rows of HPHX are more than 6. Hence, further annual energy savings will be estimated for HPHX with 6 and more rows and with RA DBT $=23{ }^{\circ} \mathrm{C}$.

\section{ANNUAL ENERGY SAVINGS FOR PUNE CONDITIONS}

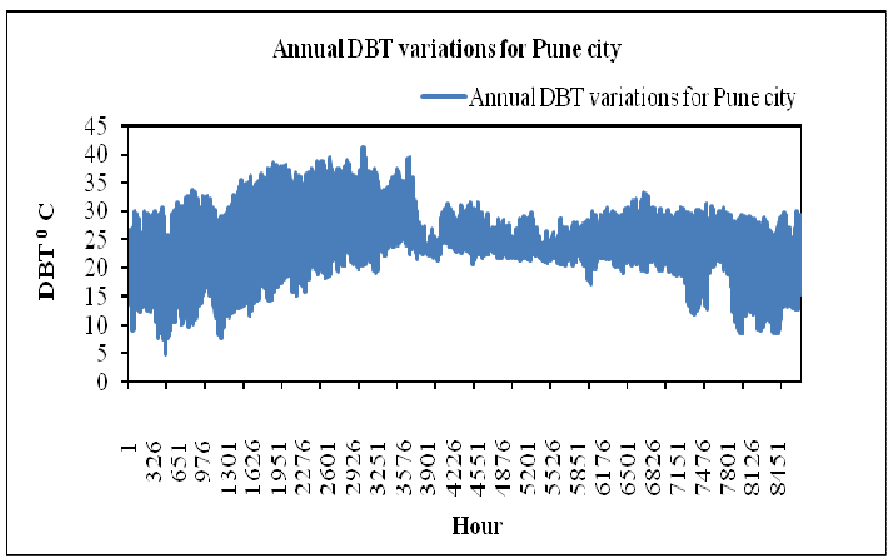

Fig - 2: Annual DBT temperature variation for Pune city $[12,13]$

Figure 2 shows the annual DBT temperature variation for Pune city $[12,13]$. Referring to the weather data files for Pune city $[12,13]$ we see that out of annual 8760 hours, the total number of hours when the minimum outdoor DBT in Pune is $25{ }^{0} \mathrm{C}$ DBT or more is 3670 hours. This accounts for approximately $42 \%$ of the annual period. Hence we can achieve tremendous energy savings by utilizing HPHX for heat recovery application. The annual energy savings for Pune city using HPHX considering that minimum outdoor 
air DBT $=25{ }^{0} \mathrm{C}$ or greater is summarized in Table 4. As seen from Table 4 , the annual energy savings will be huge when the outside air requirement is more and when the air conditioning is 24 hours $x 7$ days application.

Table - 4: Annual energy savings for Pune conditions

\begin{tabular}{|l|c|c|c|c|c|c|}
\hline \multicolumn{7}{|c|}{$\begin{array}{l}\text { Considering OA DBT }=25 \\
\text { (Total 3670 hours out of 8760 hours) }\end{array}$} \\
\hline City & \multicolumn{5}{|c|}{ Pune } \\
\hline OA Air Qty in ${ }^{3} / \mathrm{s}$ & 0.8 & 0.8 & 0.8 & 0.8 & 0.8 & 0.8 \\
\hline $\begin{array}{l}\text { Return Air (RA) } \\
\text { DBT }{ }^{0} \mathrm{C}\end{array}$ & 23 & 23 & 23 & 23 & 23 & 23 \\
\hline $\begin{array}{l}\text { No. of Rows of } \\
\text { HPHX }\end{array}$ & 6 & 8 & 10 & 12 & 14 & 16 \\
\hline $\begin{array}{l}\varepsilon_{\text {HPHX }} \\
\text { Total Energy } \\
\text { Savings, kWhr }\end{array}$ & 16812 & 17933 & 18605 & 19054 & 19502 & 19950 \\
\hline $\begin{array}{l}\text { Total Energy } \\
\text { Savings, Tonhr }\end{array}$ & 4780 & 5099 & 5290 & 5418 & 5545 & 5672 \\
\hline $\begin{array}{l}\% \text { Savings with } \\
\text { reference to } \\
6 \text { row HPHX }\end{array}$ & - & 6.7 & 10.7 & 13.3 & 16.0 & 18.7 \\
\hline
\end{tabular}

\section{CONCLUSIONS}

The paper discusses the benefits of HPHX for a process air conditioning facility located in Pune city, India.

The annual energy savings considering only heat recovery application is significant for Pune city and thus proves beneficial in facilities where ventilation air requirements are huge such as cleanroom air conditioning.

Outdoor and return DBT, outdoor and return air quantities, effectiveness of HPHX are the governing parameters that affect the overall savings in cooling coil capacity. In addition, HPHX used for dehumidification enhancement along with reheat application will also help in reducing the energy consumption of the air conditioning system.

The biggest advantage of using HPHX is that it does not require any external power for its operation. Hence further investigations on selection of working fluid, pressure drop calculations, additional fan power consumption and payback period needs to be done for different rows of HPHX for both, heat recovery application as well as dehumidification enhancement with reheat application.

\section{REFERENCES}

[1] S.W. Chi, Heat Pipe Theory and Practice: A Sourcebook, Hemisphere Publishing Corporation, (1976).

[2] Yau Y.H and M. Ahmadzadehtalatapeh, A review on the application of horizontal heat pipe heat exchangers in air conditioning systems in the tropics, Applied Thermal Engineering, Vol.30, (2010), pp. $77-84$.

[3] A. Mardiana-Idayu and S.B. Riffat, Review on heat recovery technologies for building applications, Renewable and Sustainable Energy Reviews, Vol. 16 (2012), pp. 1241 1255.

[4] G.D. Mathur, Predicting yearly energy savings using BIN weather data with heat pipe heat exchangers, in Proceeding of the Intersociety Energy Conversion Engineering Conference, Honolulu, USA, Vol. 2, (1997), pp. 1391- 1396.

[5] J.W. Wan, J.L. Zhang, W.M. Zhang, The effect of heat pipe air handling coil on energy consumption in central airconditioning system, Energy and Buildings, Vol. 39, (2007), pp. 1035 - 1040.

[6] Yau Y.H and M. Ahmadzadehtalatapeh, Predicting yearly energy recovery and dehumidification enhancement with a heat pipe heat exchanger using typical meteorological year data in the tropics, Journal of Mechanical Science and Technology, Vol. 25, No.4, (2011), pp. 847 - 853.

[7] Y.H. Yau, Application of a heat pipe heat exchanger to dehumidification enhancement in a HVAC system for tropical climates - a baseline performance characteristics study, International Journal of Thermal Sciences, Vol. 46, (2007), pp. $164-171$.

[8] Y.H. Yau, The use of a double pipe heat exchanger system for reducing energy consumption of treating ventilation air in an operating theatre-A full year energy consumption model simulation, Energy and Buildings, Vol. 40, (2008), pp. 917 - 925.

[9] M. Ahmadzadehtalatapeh and Yau Y.H, The application of heat pipe heat exchangers to improve the air quality and reduce the energy consumption of the air conditioning system in a hospital ward-A full year model simulation, Energy and Buildings, Vol. 43, (2011), pp. 2344 - 2355.

[10] M.A. Abd El-Baky, M.M. Mohamed, Heat pipe heat exchanger for heat recovery in air conditioning, Applied Thermal Engineering Vol.27, (2007), pp. 795 - 801.

[11] Product Catalogue, S \& P Coil Products Limited.

[12] Energy Efficiency and Renewable Energy (EERE), Energy plus energy simulation software - Weather data.

[13] National Renewable Energy Laboratory (NREL), Dview - Hourly simulation software.

\section{Nomenclature}

$\begin{array}{ll}\text { DBT } & \text { Dry bulb temperature } \\ \text { HPHX } & \text { Heat pipe heat exchanger } \\ \text { OA } & \text { Outdoor air } \\ \text { RA } & \text { Return (Room) air } \\ \text { RH } & \text { Relative humidity } \\ \mathrm{T}_{\mathrm{LA}} & \text { DBT of air leaving the HPHX and } \\ & \text { entering the cooling coil } \\ \mathrm{T}_{\mathrm{OA}} & \text { DBT of outdoor air entering the HPHX }\end{array}$


TR

Ton of refrigeration

$\mathrm{T}_{\mathrm{RA}}$

$\mathrm{W}$

DBT of return (room) air

WBT

Humidity ratio

$\varepsilon_{\mathrm{HPHX}}$

Wet bulb temperature

Effectiveness of heat pipe heat exchanger

\section{BIOGRAPHIES}

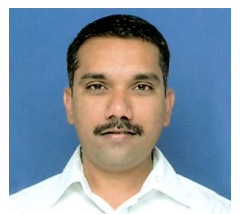

Tushar S. Jadhav has completed his Masters in Mechanical Engineering with specialization in refrigeration and air conditioning. At present, he is pursuing his Ph.D. in the area of energy savings in air conditioning. His areas of interest include heat pipes, evaporative cooling, refrigeration and air conditioning.

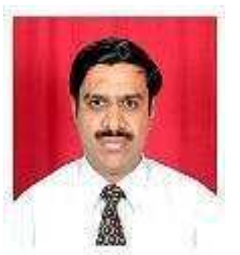

Mandar M. Lele has received his Ph.D. in 2006 from Indian Institute of Technology, Bombay. His teaching and research interests lie in the areas of thermodynamics, heat transfer, refrigeration and air conditioning, cryogenics, energy conservation. 